DOI: https://doi.org/10.31933/dijdbm.v2i2 Received: 17 January 2021, Revised: 15 February 2021, Publish: 3 March 2021

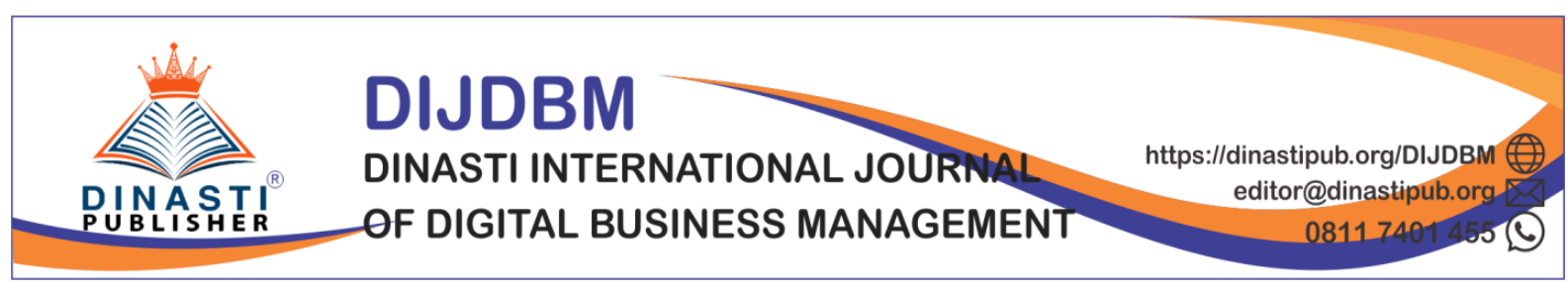

\title{
INFLUENCE WORK DISCIPLINE, ORGANIZATIONAL LEARNING, AND MOTIVATION TO EMPLOYEE PERFORMANCE AT PT CIMB NIAGA TBK
}

\author{
Riduansyah Putra', Sangkala Ruslan ${ }^{2}$ \\ ${ }^{1)}$ MercuBuana University, Jakarta, Indonesia, Riduan.riduansyahputra@gmail.com \\ ${ }^{2)}$ MercuBuana University, Jakarta, Indonesia
}

\begin{abstract}
This study aims to measure the effect of work discipline, organizational learning and motivation on employee performance at PT CIMB Niaga Tbk. This research is quantitative. The population is employees of the unsecured credit underwriter group. The sampling technique was using nonrandom sampling, namely saturated samples with a total of 221 employees. The research data were analyzed using multiple linear regression. The results of the t-test for the variables of work discipline, organizational learning, and motivation partially are significant positive on employee performance. The results of the Ftest for the variables of work discipline, organizational learning, and motivation simultaneously are significant to employee performance. Suggestions for further research are to include compensation factors as additional independent variables.
\end{abstract}

Keywords: Work Discipline; Oragnizational Learning;Motivastion; Employee Performance;

\section{INTRODUCTION}

Human resources (HR) in the company's operating system are one of the basic assets, playing an important role in achieving a company's goals. Therefore, companies need to manage and develop HR well. Because the key to the success of a company is not only the superiority of technology and the availability of funds, but the human factor is also an important factor. Human resources play an important role in every organization of company activities even though the roles and functions of the workforce have been replaced by increasingly sophisticated technology. But in fact, until now, labor is still an important factor in determining the nets of the production process. Therefore, every company wants every workforce to work effectively and efficiently. Human resource development, both those working in the public and private sectors, needs to be carried out in a planned and sustainable manner. The strategy for developing human resources, known as organizational management, must be flexible in accepting new ideas even though currently it is not suitable and can carry out some fundamental reforms to conventional policies and practices. The ability of new employees to be combined with certain employee induction and training programs, has not 
completely eliminated the gap between work ability and task demands that lead to an increase in the productivity of the organization / company as a whole (Kadarisman, 2012).

PT Bank CIMB Niaga Tbk or better known as CIMB Niaga is a bank that was founded in 1955. Currently, CIMB Niaga is the fourth largest bank in Indonesia in terms of assets, and is recognized for its achievements and excellence in customer service and management development. Currently, the majority of Bank CIMB Niaga's shares are owned by the CIMB Group. Bank CIMB Niaga is the largest KSEI payment bank by transaction value, and with a market share of $11 \%$, currently CIMB Niaga is the third largest home ownership credit provider in Indonesia.

High employee performance is expected by the company. The more employees who have high performance, the overall company performance will increase so that the company will be able to survive in global competition. Employees are required to be able to complete their duties and responsibilities effectively and efficiently. Employee success can be measured through customer satisfaction, reduced number of complaints from various internal and external parties and the achievement of optimal targets.

As a company engaged in the service sector, credit distribution carried out so far must have employees who have the ability and willingness to work hard for the progress of the company. Therefore the company must be able to motivate every employee to maximize every potential they have in order to produce optimal performance. Efforts made include providing work discipline, motivation and good organizational learning.

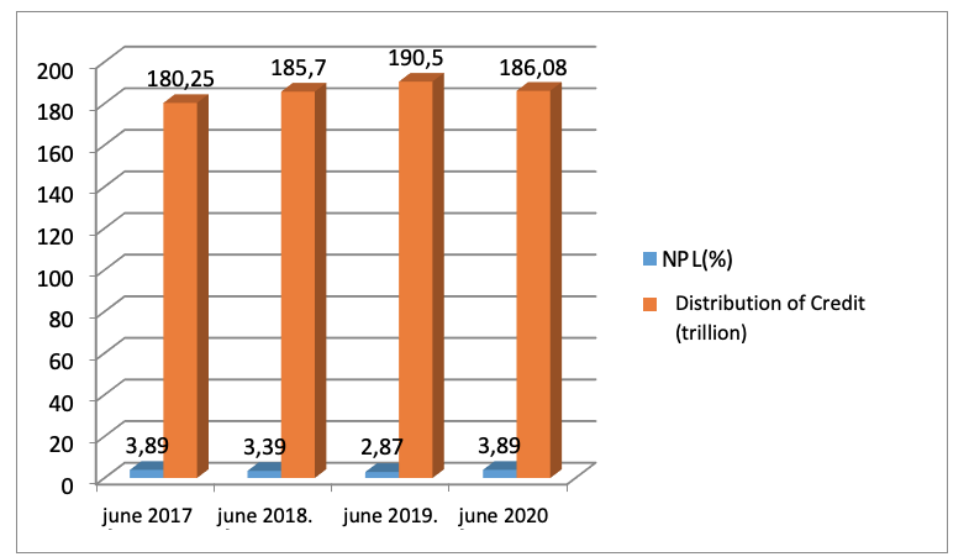

Figure 1 Diagram of NPL Data and Customer Credit Distribution

From the picture above shows a graph every June or every semester from year to year, which illustrates that there was a decrease in semester 2020. This is shown in June 2020 credit disbursement has decreased by around 185.5 trillion rupiah. Meanwhile, loan assistance in the previous year in the same month was worth 190.5 trillion rupiah. This happens due to various factors. In addition to the Covid-19 pandemic, which has decreased public consumption. This also occurs because of employees who have decreased performance. This is what makes credit distribution down. Another thing that shows a decrease is the NPL or Non Performance Loan. NPL is a non-performing loan consisting of loans classified as substandard, doubtful and non-performing. 
NPL or non-performing loans is one of the main parameters in assessing the performance of functions in the banking world. The graph above shows that the NPL in June 2020 increased to $3.89 \%$, an increase in the previous year of the same month, namely $2.87 \%$. This shows that Cimb Niaga cannot suppress bad credit with management and employee performance in the midst of the current pandemic. Even if it is seen from the two graphs that have decreased in credit distribution but experienced an increase in NPL, it makes cimb niaga have to improve banking management and the performance of their employees.

The fenomena in this study is that in addition to the decline in overall employee performance due to various problems both internally and externally. The causes of decreased employee performance include low employee discipline and work ethic, this is indicated by decreased employee interest in achieving work performance, a work team that has also decreased enthusiasm and there are no examples that should be used as a reference in achieving good work performance and lack of motivation. employees because there is no job guarantee.

\section{LITERATURE REVIEW Performance}

Performance is the result of work and work behavior that has been achieved in completing assigned tasks and responsibilities within a certain period. Kasmir (2015: 181) From the above understanding in performance, it means that performance is the result of a person's work and work behavior in a period, usually 1 year. Then performance can be measured by its ability to complete the tasks and responsibilities given. This means that performance contains elements of achievement standards that must be met, so that those who achieve the predetermined standards are performing well or vice versa for those not achieved are categorized as underperforming or not well. Kasmir (2015: 182).

\section{Employee Retention}

According to Susilo (2013), employee retention is the desire of employees to stay with the company for a long time. Companies must pay attention to and maintain employees as well as possible, otherwise the employee's morale, loyalty, attitude and discipline will decrease. Retention also involves eliminating low-performing employees to increase space and more resources for employees who are performing well. In other words, retention policies should focus on eliminating what's bad for the company and retaining the best employees.

Employee retention according to Robert L. Mathis and John H. Jackson (2010) is the ability of the company to retain the company's potential employees to remain loyal to the company. The goal is to retain employees who are considered qualified by the company at the will of the employees themselves. So that employee retention is a must that companies need to do in order to maintain the best Human Resources (HR) they have.

Meanwhile, employee retention can also be done to be able to find solutions in order to minimize employee turnover and increase employee comfort in a company. Companies and employees both need each other, therefore doing the best from both parties is something that needs to be done. 


\section{Work Disciplin}

According to Edy Sutrisno (2014: 86) Work discipline is an attitude of a person's willingness and willingness to obey and obey the prevailing regulatory norms around him. According to Hasibuan (2014: 193) discipline is the most important HR operative function because the better employee discipline, the higher work performance they can achieve. Without good employee discipline, it is difficult for company organizations to achieve optimal results.

\section{Organizational Learning}

According to Finger and Brand quoted by Suharsaputra (2015: 71), "Organizational learning is the activity and the process by a wich organization eventually reach the ideal of a learning organization". Organizational learning is the activity and process by which the organization finally achieves its goals as a learning organization. Organizational learning is the achievement of additional knowledge, both individually and in groups that are determined in an effort to achieve organizational goals. This means that the learning carried out by members of the organization must be part of an organizational system, the application of learning outcomes that occurs will be the main driving force and support in the efforts of all members of the organization.

\section{Motivation}

Motivation is an encouragement from others and from oneself to do a job consciously and enthusiastically to achieve certain targets. (Mulyadi, 2015: 87)

\section{RESEARCH METHODS}

In this case the research uses a causal research design. Causal design is useful for measuring the relationships between research variables or is useful for analyzing how a variable affects other variables (Umar, 2010: 10). So in this study to determine whether work discipline, learning organization and motivation as independent variables affect work performance as the dependent variable.

The population in this study were all employees of Bank CIMB Niaga, part of the Unsecured Credit Underwriting Group, totaling 221 employees.In this study, using multiple linear regression calculations. This study uses multiple regression analysis because it has two or more variables (X), using the SPSS (Statistical Package for Social Science) program version 25 .

The sample in this study used a nonprobability sampling category in the form of saturated sampling. According to Indra and Cahyaningrum (2019: 54) nonprobability sampling is a sampling technique in which every member of the population does not get the same opportunity to be selected. According to Sugiyono (2014: 126) saturated sampling is a sampling technique if all members of the population are used as samples and are often carried out in small populations or in research that wants to make generalizations with a relatively small error rate.

Data collection techniques in this study were conducted by conducting surveys and distributing questionnaires directly to the research object, namely the employees of Bank 
Cimb Niaga, the unsecured credit underwriting group. The questionnaire is a data collection technique by providing or distributing a list of statements to respondents in the hope that they will respond to the list of questions (Sugiyono, 2012: 126).

The data in this study uses primary data derived from questionnaires, therefore before testing the hypothesis, it is necessary to test the validity and reliability of the indicators or questionnaire questions. In analyzing the data the methods used include:

- Descriptive statistics

- Validity test

- Reliability Test

- Linearity Test

- Classic assumption test
a) Normality test
b) Multicollinearity Test
c) Heteroscedasticity Test

- Hypothesis testing
a) F test
b) $\mathrm{T}$ test
c) $R^{2}$ test
d) Inter-Dimensional Correlation Analysis

\section{FINDINGS AND DISCUSSION Validity and Reliability Test}

Reliability test is used to see the consistency of the research instrument or it can be said to what extent the research instrument can be consistent if it is used repeatedly for different periods of time. The reliability test in this study used the Cronbach Alpha formula with the help of SPSS 25. The results of the reliability test for each research variable will be presented in the table below

Table 1 Reliabilities Test

\begin{tabular}{cccc}
\hline Variable & Cronbac'h Alpha Value & N & Description \\
\hline Work Disciplin $\left(\mathrm{X}_{1}\right)$ & 0.895 & 9 & Reliabel \\
Organizational Learning $\left(\mathrm{X}_{2}\right)$ & 0.910 & 12 & Reliabel \\
Motivation $\left(\mathrm{X}_{3}\right)$ & 0.913 & 15 & Reliabel \\
Performance $(\mathrm{Y})$ & 0.794 & 12 & Reliabel \\
\hline
\end{tabular}

\section{Normality Test}

The normality test has the results which can be seen in the table below:

Table 2 Normality Test Results

\begin{tabular}{llr}
\hline One-Sample Kolmogorov-Smirnov Test & \\
\hline $\mathrm{N}$ & \multicolumn{2}{l}{$\begin{array}{l}\text { Unstandardized } \\
\text { Residual }\end{array}$} \\
\hline Normal Parameters & \\
& Mean & 221 \\
Most Extreme Differences & Std. Deviation & Absolute \\
\hline
\end{tabular}




\begin{tabular}{|c|c|c|}
\hline $\begin{array}{l}\text { Test Statistic } \\
\text { Asymp. Sig. (2-tailed) }\end{array}$ & $\begin{array}{l}\text { Positive } \\
\text { Negative }\end{array}$ & $\begin{array}{r}0.055 \\
-0.055 \\
0.055 \\
0.096^{\mathrm{c}, \mathrm{d}} \\
\end{array}$ \\
\hline $\begin{array}{l}\text { a. Test distribution is } \mathrm{N} \\
\text { b. Calculated from data } \\
\text { c. Lilliefors Significance } \\
\text { d. This is a lower boun }\end{array}$ & rue sian. & \\
\hline
\end{tabular}

(Source: data processing, 2020)

The criteria for evaluating the One-Sample Kolmogorov-Smirnov Test is if it is asyimp. $\mathrm{Sig}<0.05$, then the data is not normally distributed. If asyimp. Sig $>0.05$, then the data is normally distributed. In Table 1 shows a result of 0.096 which means that it is greater than 0.05 . This means that the residual data is normally distributed.

\section{Multicollinearity Test}

The results of multicollinearity testing in this study will be displayed in the table below:

Table 3 Multicollinearity Test Results

\begin{tabular}{llll}
\hline Independent Variable & $\begin{array}{l}\text { Value } \\
\text { Tolerance }\end{array}$ & $\begin{array}{l}\text { VIF } \\
\text { Value }\end{array}$ & Result \\
\hline Work Discipline $\left(\mathrm{X}_{1}\right)$ & 0.127 & 7.861 & Non Multikolinieritas \\
Oganizational Learning $\left(\mathrm{X}_{2}\right)$ & 0.192 & 5.201 & Non Multikolinieritas \\
Motivation $\left(\mathrm{X}_{3}\right)$ & 0.174 & 5.760 & Non Multikolinieritas \\
\hline
\end{tabular}

(Source: data processing, 2020)

In table 3, the tolerance value for all variables is greater than 0.1 and the VIF value for all variables is less than 10 , so it can be concluded that the regression model in this study is free from multicollinearity between independent variables.

\section{Heteroscedasticity Test}

The results of heteroscedasticity testing can be seen in the following table:

Table 4 Heteroscedasticity Testing Results

\begin{tabular}{lll}
\hline Independent Variable & Sig. & Results \\
\hline Work Discipline $\left(\mathrm{X}_{1}\right)$ & 0.261 & Non Heteroskedastisitas \\
Organizational Learning $\left(\mathrm{X}_{2}\right)$ & 0.056 & Non Heteroskedastisitas \\
Motivation $\left(\mathrm{X}_{3}\right)$ & 0.830 & Non Heteroskedastisitas \\
\hline
\end{tabular}

(Source: data processing, 2020)

In Table 4 the value of Sig. on all independent variables greater than 0.05 . This indicates that all independent variables do not have heteroscedasticity symptoms in the residual data.

\section{Multiple Linear Regression Analysis}

The following table will be presented based on the results of the multiple linear analysis test:

Table 5 Results of Multiple Linear Regression Analysis

Coefficients $^{\mathrm{a}}$

Unstandardized
Coefficients

Model

1 (Constant)
8.081
Std. Error

0.428
Standardized

Coefficients

Beta

Beta $\quad T$
$T_{18.896}$ Sig. 0.000 


\begin{tabular}{lccccc}
$\begin{array}{l}\text { Work } \\
\text { Discipline } \\
\left(X_{1}\right)\end{array}$ & 0.404 & 0.039 & 0.394 & 10.241 & 0.000 \\
$\begin{array}{l}\text { Organization } \\
\text { al Learning } \\
\left(X_{2}\right)\end{array}$ & 0.244 & 0.024 & 0.318 & 10.152 & 0.000 \\
$\begin{array}{l}\text { Motivation } \\
\left(X_{3}\right)\end{array}$ & 0.199 & 0.021 & 0.307 & 9.300 & 0.000 \\
\hline
\end{tabular}

a. Dependent Variable: Kinerja

(Source: Data Processed 2020)

In Table 5 in the Unstandardized Coefficients column B shows a constant value $(\alpha)$ of 8,081 and in the next row the coefficient of the independent variable (b) is Work Discipline of 0.404; Organizational Learning is 0.244 and Motivation are 0.199 , the regression equation can be arranged as follows:

$\mathrm{Y}=\alpha+\beta 1 \mathrm{X} 1+\beta 2 \mathrm{X} 2+\beta 3 \mathrm{X} 3+\mathrm{e}$

$\mathrm{Y}=8,081+0,404 \mathrm{X} 1+0,244 \mathrm{X} 2+0,199 \mathrm{X} 3+\mathrm{e}$

Based on the regression equation previously described, it can be explained as follows:

1. This constant $(\alpha)$ indicates that if all independent variables have a zero value $(0)$, the value of the dependent variable (Beta) is 8,081 .

2. A constant value of 8,081 indicates that if the variables of Work Discpline (X1), Organizational Learning (X2), and Motivation (X3) are in constant condition, the Decision to Choose (Y) is 8,081.

3. Work Discipline (X1) to Voting Performance (Y). The regression coefficient for the Work Discipline (X1) is 0.404 and is positive. This indicates that the location has a direct relationship with the Decision to Choose. This also implies that every one-unit decrease in the value of Location, the value of the Voting Perfomance variable (Y) will decrease by 0.404 with the assumption that the value of the other independent variables in the regression model is fixed.

4. Organizatioonal Learning (X2) of Voting Perfomance (Y). Organizatioonal Learning variable regression coefficient (X2) is 0.244 and is positive. This shows that Promotion has a direct relationship with the Choosing Decision. This also implies that every one-unit decrease in the value of Promotion, the value of the Voting Perfomance variable (Y) will decrease by 0.244 with the assumption that the value of the other independent variables in the regression model is fixed.

5. Motivation (X3) on Voting Performance (Y). The regression coefficient for the Motivation variable (X3) is 0.199 and is positive. This indicates that the Motivation has a direct relationship with the Voting performance. This also implies that each increase in the value of one unit of motivation, the value of the Performance variable (Y) will increase by 0.199 with the assumption that the value of the other independent variables in the regression model is fixed. 


\section{F-Test}

F-test results using SPSS 25 will be presented in the table below:

Tabel 6 F-Test Results

ANOVA $^{\mathrm{a}}$

\begin{tabular}{llrrrrr}
\hline Model & & Sum of Squares & Df & \multicolumn{1}{c}{ Mean Square } & F & \multicolumn{1}{c}{ Sig. } \\
\hline 1 & Regression & 3139.986 & 3 & 1046.662 & 96.005 & $.000^{\mathrm{b}}$ \\
& Residual & 1046.604 & 96 & 10.902 & & \\
& Total & 4186.590 & 99 & & & \\
\hline
\end{tabular}

a. Dependent Variable: the decision to choose

b. Predictors: (Constant), location, promotion, people

(Source: data processing, 2020)

In Table 6 the Sig. equal to 0.000 and less than 0.05. This means that the variables of Work Discipline, Organizational Learning, and Motivation together have a significant effect on the Choosing Performance (H4 accepted).

\section{T-test}

The results of the $t$ test calculation can be seen below:

- H1: Work Discipline variable has a t value of 10.241> 1.9708 (t table) and has a Sig. 0.000 is less than 0.05 . This means that work discipline has a significant effect on performance.

- H2: Organizational Learning Variable has a t value of 10,152>1.9708 (t table) and has a Sig. 0.000 is less than 0.05 . This means that Organizational Learning has a significant influence on performance.

- H3: Work Motivation Variable has a t value of 9.300> 1.9708 (t table) and has a Sig. 0.000 is less than 0.05 . This means that work motivation has a significant effect on performance.

- The highest value on standardized coefficients beta is in the Work Discipline variable, which is 0.394 . This shows that the variable that has the greatest influence on performance is work discipline.

\section{$\mathbf{R}^{2}$ Test}

The results of the determination test can be seen in the following table:

\begin{tabular}{|c|c|c|c|c|}
\hline Model & jummary & Table $7 \mathrm{R}$ & st Results & \\
\hline Model & $\mathrm{R}$ & R Square & $\begin{array}{l}\text { Adjusted R } \\
\text { Square }\end{array}$ & $\begin{array}{l}\text { Std. Error of } \\
\text { the Estimate }\end{array}$ \\
\hline 1 & $0.979^{a}$ & 0.959 & 0.958 & 1.210 \\
\hline
\end{tabular}

(Source: data processing, 2020) 
In Table 7, the R2 value is 0.959 , which means the Work Discipline, Organizational Learning, and Motivation variables contribute 95,9\% to the Voting Performance variable while the remaining $4,1 \%$ is explained by other variables.

\section{Matrix Correlation}

Correlation test results using the Pearson's Correlation two-tailed method and will be described in the following table:

Table 8 Correlation Matrix Between Dimensions

\begin{tabular}{|c|c|c|c|c|c|}
\hline \multirow[b]{2}{*}{ Variable } & & \multicolumn{4}{|c|}{ Performance } \\
\hline & Dimension & $\begin{array}{l}\text { Number of } \\
\text { Jobs }\end{array}$ & Job Quality & On Time & Presence \\
\hline \multirow{3}{*}{$\begin{array}{l}\text { Work } \\
\text { Disciplin }\end{array}$} & Purpose & 0,823 & 0,774 & 0,753 & 0,787 \\
\hline & Support & 0,781 & 0,704 & 0,773 & 0,773 \\
\hline & Determinant & 0,801 & 0,761 & 0,782 & 0,777 \\
\hline \multirow[t]{5}{*}{$\begin{array}{l}\text { Organizational } \\
\text { Learning }\end{array}$} & $\begin{array}{l}\text { System } \\
\text { Thinking }\end{array}$ & 0,768 & 0,683 & 0,696 & 0,734 \\
\hline & $\begin{array}{l}\text { Personal } \\
\text { Mastery }\end{array}$ & 0,623 & 0,582 & 0,655 & 0,657 \\
\hline & $\begin{array}{l}\text { Mental } \\
\text { Models }\end{array}$ & 0,689 & 0,619 & 0,659 & 0,693 \\
\hline & Shared Vision & 0,762 & 0,675 & 0,722 & 0,715 \\
\hline & $\begin{array}{l}\text { Team } \\
\text { Learning }\end{array}$ & 0,795 & 0,721 & 0,749 & 0,781 \\
\hline \multirow[t]{5}{*}{ Motivation } & Fisiologi & 0,765 & 0,747 & 0,724 & 0,785 \\
\hline & $\begin{array}{l}\text { sense of } \\
\text { secure }\end{array}$ & 0,725 & 0,690 & 0,735 & 0,738 \\
\hline & $\begin{array}{l}\text { accepted by } \\
\text { the group }\end{array}$ & 0,730 & 0,725 & 0,670 & 0,734 \\
\hline & Prride & 0,712 & 0,682 & 0,758 & 0,746 \\
\hline & $\begin{array}{l}\text { self- } \\
\text { actualization }\end{array}$ & 0,778 & 0,694 & 0,725 & 0,742 \\
\hline
\end{tabular}

(Source: data processing, 2020)

Based on Table 8. In the Work Discipline variable, the Goal dimension has the strongest relationship with the Total Work dimension in the Performance variable of 0.823 . While the weakest relationship is the Support dimension to the Quality of Work dimension of 0.704 .

In the Organizational Learning variable, the dimension with the strongest relationship was the Team Learning dimension towards the Total Work dimension in the Performance variable of 0.795 while the weakest relationship was the Personal Mastery dimension to the Job Quality dimension of 0.582 .

In the Motivation variable, the dimension with the strongest relationship is Physiology to the Attendance dimension of the Performance variable of 0.785 while the weakest relationship is the Acceptable Group dimension to the Timeliness dimension of 0.670 . 


\section{CONCLUSION AND SUGGESTION}

Based on the results of data processing that have been described in the previous chapter regarding "The Effect of Work Discipline, Organizational Learning, and Motivation on Employee Performance at PT CIMB Niaga tbk", the following conclusions can be drawn:

1. Work Discipline has a significant positive effect on Employee Performance. The objective dimension correlates the highest with the number of jobs, the variable of performance. This is in accordance with the company's objectives, where the company requires employees to improve performance by optimizing the number of jobs available so that good work results are created that have an impact on excellent customer service.

2. Organizational Learning has a significant positive effect on Employee Performance. The Team Learning dimension has the highest correlation with the Number of Jobs dimension. This is in accordance with the conditions of the organization which give responsibility to its employees to train the organization to complete the amount of work faster and more.

3. Motivation has a significant positive effect on employee performance. The Physiological dimension has the highest correlation with the Presence dimension. This happens because employees make company performance a motivation for work. So that the presence of employees is influenced by the physiology of the employees in increasing motivation at work.

4. Work Discipline, Organizational Learning, and Motivation simultaneously have a significant effect on employee performance. This happens because the condition of employees who need an increase in performance by improving various aspects in it such as discipline in work, organizational learning that is always improved and controlled and motivation that can increase employee passion, such as rewards for exemplary employees and punishment for employees who violate. company disciplinary regulations or not achieving targets at work

Adviced for Unsecure Credit Underwriting Group.Based on the research results and conclusions that have been previously described, the researcher provides suggestions for leaders and researchers who will further research as follows:

1. Researchers can then include other factors that can affect employee performance outside of this study.

2. Leaders should simultaneously improve Work Discipline, Organizational Learning, and Motivation from employees to be more effective in increasing employee performance. In this case, employee organizational learning becomes a priority to be improved.

3. Employee leaders are expected to be able to determine the goals of the work that can increase the amount of work done on a daily basis for employees. This suggestion is taken based on the relationship of the strongest dimensions of work discipline, namely the dimension of goals in the dimensions of the number of jobs on employee performance.

4. Employee leaders are expected to improve organizational training and learning about teamwork in organizations. This is in line with the strongest dimension of organizational learning, namely the Team Learning dimension of the number of jobs for employee performance.

5. Employee leaders are expected to increase motivation by providing comfortable and safe work facilities so as to make employees enthusiastic about working. That way employees will fulfill work attendance optimally so as to produce good work results. This suggestion 
is taken based on the strongest dimensional relationship, namely the physiological dimension and the attendance dimension of employee performance.

6. The organization is expected to increase the productivity of the company by implementing good work discipline by providing punishment for employees who violate company regulations, training and learning in a sustainable organization, as well as employee motivation in working by providing rewards for employees who excel.

7. Employees are expected to improve their performance with good work discipline with full responsibility and selflessness, apply the results of training and organizational learning well, and have enthusiastic work motivation for the sustainability of the company's business.

8. The company is expected to be able to apply good work discipline to its employees by making rules that can be obeyed by employees, creating training and organizational learning for employees so that employees can work optimally both in groups and individually, and increase employee motivation. by providing rewards in the form of incentives or awards to outstanding employees. So that it can increase business productivity, company profits, and can compete with other companies well.

9. With the application of work discipline, organizational learning, and motivation to employee performance, it is expected that it will improve financial performance, increase business, and increase good assets for CIMB Niaga so that people can calmly and trust to invest, do business, and make transactions using CIMB Commerce.

\section{REFERENCE}

Hasibuan, M. S. (2014). Manajemen Sumber Daya Manusia . Jakarta: Bumi Aksara.

Husein, Umar. 2010. Metode Penelitian Untuk Skripsi dan Tesis Bisnis Edisi 11. Jakarta: PT Raja Grafindo Persada.

Kadarisman, M. 2012. Manajemen kompensasi. Jakarta: Rajawali pers.

Kasmir. (2015). Manajemen Sumber Daya Manusia. Jakarta: Rajawali Pers.

Mulyadi. (2015). Manajemen Sumber Daya Manusia. Penerbit In Media. Jakarta.

P, I Made Indra dan Ika Cahyaningum. (2019). Cara Mudah Memahami Metodologi

Penelitian. Yogyakarta: Deepublish.

Mathis, Robert L. dan Jackson John H. (2010). Human Resource Management $13^{\text {th }}$ ed.Thomson. South-Western.

Sugiyono. (2012). Metode Penelitian Kuantitatif, Kualitatif dan R\&D. Bandung: Alfabeta.

Sugiyono. (2014). Metode Penelitian Pendidikan Pendekatan Kuantitatif, Kualitatif, dan R\&D. Bandung: Alfabeta.

Susilo, A. (2013). Pengaruh Retensi Karyawan dan Kepuasan Pelanggan terhadap Kinerja. 1(3), 247-262.

Sutrisno, Edy. 2014. Manajemen Sumber Daya Manusia. Cetak Ke Enam. Pranada Media Group, Jakarta.

Suharsaputra,Uhar.(2013). Administrasi Pendidikan, Cet. Ke-2 (Edisi Revisi), Bandung: PT Refika Aditama. 